\title{
Mikołaj Góralik*
}

\section{Sci-fEAST: Science fiction genre in Polish and Czechoslovakian cinema}

This article is based on research done as part of Sci-fEAST: the Science Fiction Genre in Central and Eastern Europe project initiated by the students of Charles University in Prague and continued also by the academic staff of the University of Łódź since September 2012. The goal of the project was to create a comprehensive database of science fiction films specific for particular national cinemas and so far all of the Czech and Polish full-length feature films have been collected. It is planned that the Hungarians and Slovaks will join the project as well, adding to the database both works of Hungarian cinema and films made after the Dissolution of Czechoslovakia. The http://www. sci-feast.eu webpage, also available in English, is being gradually updated as new TV-productions as well as short-feature films are added. The latter, especially in the case of Polish cinema, constitute a significant part of all the works of the genre. This freely accessible database provides descriptions of the films together with technical data and a short synopsis of the plot, but its intended purpose is to be a discussion platform (of thought exchange) between the particular universities and scholar communities . Additionally, the database includes articles on Middle-European science fiction cinema and is a place where information concerning lectures and conferences on the science fiction genre as well as science fiction themed screening programs at film festivals is gathered. In one of his articles, Alexandr Jančík ${ }^{1}$ tries to discuss the phenomenon of online databases, and includes works of Czech audiovisual culture from Artyčok.TV, the internet television website, which presents archive works, the artlist.cz webpage, which gathers written and visual sources and the portal jlbjlt.net whose goal is to provide information on a wide variety of cultural events. According to the author, at present, this form of presentation of audiovisual works promotes them better and more efficiently than any anthology or encyclopaedia. At the same time, Jančík observed that paradoxically, none of the websites concerned motion pictures, only. In his article from 2010, this Czech film scholar wished that an online platform such as Sci-fEAST

* Uniwersytet Łódzki.

${ }^{1}$ A. Jančík, On-line databáze českého audiovizuálního umění, [in:] Současný český a slovenský film - pluralita estetických, kulturních a ideových konceptů, ed. L. Ptáček, Palacký University, Olomouc 2010, p. 127-139. 
had existed before - an internet database devoted to films of one genre only, presenting a full picture of the development of science fiction cinema looking back over decades of film history. It is no coincidence that the project concerns countries of this region, which are thoroughly analyzed in Visegrad Cinema: The Points of Contact. Furthermore, within science fiction cinema one might observe different attitudes to the genre presented by Middle-European and Anglocentric filmmakers. I do not intend to analyse the methodological problems which have emerged during a phase of constructing a consistent definition of the science fiction cinema, thanks to which it is possible to decide which of the films should be added to the database and which of them should be rejected as they do not meet the criteria of a science fiction film (this issue is discussed thoroughly on the previously-mentioned webpage of the Sci-fEAST project). Instead, I would like to use an already finished list of Czech and Polish science fiction films in order to present one of the possible views on Middle-European cinema - an intercultural perspective. The idea of an internet film database, based more on a spatial than chronological arrangement of its contents makes it possible to juxtapose all the films available in a few seconds and in different configurations, with the use of a selective browser, which makes it user-friendly and encourages people to want to use it. If, in addition, science fiction which, according to Roger Caillois, is the third - apart from fairytales and fantasy stories - imaginative genre presenting the changeable situation of mankind on the planet, ${ }^{2}$ becomes a subject for examination, films of this genre seem to be a perfect example of double meaning. When theses formulated by Caillois related to literary works are transferred to the field of the cinema, one might observe that science fiction has always been a genre which has enabled authors to present themes which would have been impossible with the use of other genres, e.g. the well-known case of the invasion of Mars with the Red Planet standing as an example of a visual representation of the danger of communism. These films form a kind of alternative history: fears which are not presented directly are hidden behind the facade of the genre, which is constructed from concealed messages, warnings, and themes veiled by allegorical convention. According to Tadeusz Lubelski, this perspective is especially useful when constructing a film history. ${ }^{3}$ The basic difference is that in comparison with a non-existent history, these films were actually produced, but among other works of Polish cinema, (apart from a few exceptions) they are now totally forgotten or treated as single texts, out of context, and do not function in relation to other works of this genre. However, when it comes to Czech cinema, as a result of a hybridization of a genre, i.e. a blending of different styles in one work, science fiction films are, for instance, received as comedies in a science fiction convention. The science fiction genre is usually unappreciated or films of this kind are only exceptions in filmographies

${ }^{2}$ R. Caillois, Science fiction, [in:] Spór o SF. Antologia, eds. R. Handke, L. Jęczmyk, B. Okólska, Wydawnictwo Poznańskie, Poznań 1989, p. 179.

3 T.Lubelski, Wstep: pokusa historiialternatywnej, [in:] Historia niebytakina PRL, Wydawnictwo Znak, Kraków 2012, p. 14. 
of particular authors. The examples of the films which I would like to present are obviously of my choice. Nonetheless, I believe that on the basis of a list of all the Polish and Czech science fiction films, I made a selection which reflects the actual possibilities of these national cinemas, whilst at the same time, choosing those titles which make it possible to formulate a general view on the themes and problems discussed by the filmmakers. The main goal of this article is to show that Middle-Eastern European cinema should not be treated as one single entity in relation to the Western film industry as even Polish and Czech films differ from each other to a great extent. As the subject of my work suggests, I intend to focus on Czechoslovakian films. Considering the fact that before the creation of Czechoslovakia, i.e. till 1918, not a single science fiction film had been made, and the cinema after 1989 is not a subject of my interest here and the article does not concern those films created after the Dissolution of Czechoslovakia. I believe that when political censorship was lifted, despite the presence of social censorship and economical obstacles determining the final shape of the films, the science fiction genre lost its function of commenting on the political situation, and has become a marginal and uninteresting phenomenon in both of the two film industries. Before that point, however, many interesting films were produced; I do not assess their artistic value, formal aspect nor the way they are structured. Instead, I will do a kind of review of the most interesting visions concerning space missions, Homunculi, time travel experiments and attempts to change the course of history presented in Czech and Polish films.

\section{Where Can You (Time) Travel in the Czechoslovakian Science Fiction Cinema?}

During the interwar period, Czech filmmakers released only two films alluding to the imminent danger of fascism which was inevitably leading to the next military conflict. The first one of the two was The World Is Ours (Svět patrí nám), a 1937 film based on Rub a lic, a theatrical play by a famous comic duo - Jiří Voskovec and Jan Werich. The second film, produced in the same year, was The White Disease (Bílá nemoc) by Hugo Haas, the first Czechoslovakian science fiction work, which was an adaptation of Karel Čapek's novel of the same title. Haas, an actor of Jewish origin, until then associated with light comedy roles, decided to direct a film about a deadly disease which was a punishment for the wrongdoings of the people. He also played the leading role of Doctor Galén who finds an antidote to the disease but refuses to cure the rich as long as they do not bring about peace in the world. The White Disease is another example of a film portrayal of a dictator in the history of the cinema.

The answer to the question if there was a war is that it would be a sin not to let it break out as the country (the action takes place in a fictional state) has an excellent leader and a huge army. The film ends with the lynching of 
the protagonist who tries to avert the conflict but war breaks out because the fanatical leader of the nation, who is also infected by the disease, assumes it is a message from God and, in the last moments of his life, decides to sign a truce. Nevertheless, actual reality turned out to be far worse than the film, as war broke out soon after and Haas, because of his Jewish origin, had to go abroad where he successfully continued his career as a Hollywood filmmaker.

The first post-war science fiction film, Krakatit (1948) directed by Otakar Vávra, was another adaptation of Čapek's prose. Once again, the protagonist is a scientist. This time, an engineer called Prokop who, instead of an antidote, possesses knowledge of a formula for an explosive substance which puts mankind in danger. As a screen-caption suggests, the story takes place between reality and the dreams of an unidentified man suffering from a fever. The sequence of events, beginning with the scene in which he arrives at a hospital, constitutes the narrative structure of the main story about the invention of krakatit. The audience find themselves in the middle of a story where Prokop is delirious and suffering from partial amnesia and gradually becomes conscious of the detrimental effects of his invention. It turns out that the only solution to the problem is to get rid of all the remaining krakakit which has fallen into the wrong hands. The film was created in the critical year of 1948 when the socialist realism was announced and the government imposed strict censorship on all screenplays which had to adhere to communist party guidelines from then on. Nevertheless, Krakatit, which Vávra had planned to adapt a long time before then, remained free from ideological interference with the film's plot. As Mariusz Guzek correctly observes, the director incorporated two different narratives styles into the film - a literary and a journalistic one. The first derived from Ćapek's novel, the second was a result of the experience of the last war, focusing mainly on the perspective of the mass destruction caused by a nuclear bomb. ${ }^{4}$ After some years, Vávra returned once again to Čapek's Krakatit, directing Dark Sun (Temné slunce, 1980), a film loosely related to its literary model, but indisputably alluding to the climate of Cold War tension. According to Guzek, by setting the action in an undefined future and surroundings similar to the one of the crazy comedies (bláznive komedie), Vávra unintentionally created a comical effect. Science fiction enabled Czechoslovakian comedy writers to produce work in a period of normalization and discuss issues such as bribery, consumerism and abuse of power, which they could not have done outside this genre. ${ }^{5}$ Nevertheless, the tone of the two Vávra pictures was definitely serious.

The Man in Outer Space (Mužz pruního století, 1961), a comedy by Oldřich Lipský, is chronologically the third film which I would like to discuss. The film is intriguing to such an extent that even nowadays critics have different opinions on its nature as to whether it was a parody of the communist system or just

${ }^{4}$ M. Guzek, "Krakatit" $i$ "Ciemne stońce" - adaptacje prozy Karela Čapka autorstwa Otakara Vávry, [in:] Hrabal i inni. Adaptacje czeskiej literatury, eds. E. Ciszewska, E. NurczyńskaFidelska, Wydawnictwo Uniwersytetu Łódzkiego, Łódź 2013, p. 14.

${ }^{5}$ Ibidem, p. 25. 
the reverse, its apology. What is interesting is the fact that the film's protagonist, Josef, once again finds himself in a situation where he might actually change the course of history. Moreover, at the beginning, Josef has no idea that he has travelled to the future. He discovers that nothing reminds him of a beautiful Czech landscape from the past and he cannot adapt to a world without money, where everyone is equal, and social hierarchy is no longer significant. The scientists from the future are amazed by the way he acts - Josef wants to own everything, which seems to be unconventional behaviour in a perfect communist system. Subsequently, Josef discovers that the only place where he feels good is in the museum of the 20 century. Josef has moved to the future by accident and he now pretends to be someone special who is endowed with exceptional wisdom as a representative of humanity from the past (but it is no accident that he has Czech nationality!). Finally, his real identity is revealed and he has to escape back to the past. In the last scene, men from the future, who represent a modern progressive society, look directly into the camera and warn us: "People, be aware that he is coming back". On the day of the premiere, the film was widely commented on in the press. Journalists focused mainly on the attitude of the protagonist. What is interesting is that none of the reviews focused on the critique of the current political system depicted in the film: why do people from the future not understand Josef's great fear of his boss; they are surprised that it is important for him whether he is in Eastern or Western Europe; finally, they do not understand his obsession with being followed. ${ }^{6}$ According to Petra Dominková, the critics ignored this undertone in the film as they just could not have coped with it. In one of the interviews Lipský, the author himself, commented on this situation as follows: "The fear which concerned the people from the future was already visible during the meeting of the committee approving the screenplay. It was obvious that one should not make fun of the future". ${ }^{7}$ In my opinion, behind the facade of the inevitable compromises which the scriptwriter must have made at the beginning of the 1960s, the film, especially its ironic ending, definitely ridicules and does not glorify the political system of that time.

Next, I would like to focus on the article Legally Seeking a Better Future by Martin Mišúr, in which the author creates a typology of Czechoslovakian films concerning the Third Industrial Revolution. ${ }^{8}$ The utopian vision of the future presented in The Man in Outer Space is not treated by the author as an obvious representation of paradise. What seems to be significant is that almost every one of the films selected by Mišúr which focuses on this theme is a comedy and none of them is a critique of the vision of the future. ${ }^{9}$

${ }^{6}$ P. Dominková, $K$ interpretacím "Muže z pruního stoletî", [in:] Interpretácia a film, ed. M. Kaňuch, Asociácia Slovenských Filmových Klubov, Bratislava 2008, p. 115.

7 Ibidem, p. 116-117.

${ }^{8}$ M. Mišúr, Dovolené hledání světlých zítrků - československé filmové sci-fi v reakci na koncept vědeckotechnické revoluce, http://www.sci-feast.eu/index.php?page=text\&id=49 (access: 20.05.2014).

9 Ibidem. 
One of the Czech members of the Sci-fEAST team did not take into account a 1966 science fiction drama The End of August at the Hotel Ozone (Konec srpna $v$ hotelu Ozon). This film by Jan Schmidt, based on Pavel Juráček's screenplay, was produced during a specific period of the political thaw of the first half of the 1960s along with the whole formation of the Czechoslovakian New Wave. Most of these films, such as works by Menzel, Forman and Passer, are treated nowadays as extremely accurate representations of past times with ordinary characters with their own down-to-earth problems. Schmidt, on the other hand, offered a vision of the world after a nuclear apocalypse, which is traversed by eight young girls led by an old woman, the only person who remembers the world before the explosion. Her goal is to find the men who survived the catastrophe and to repopulate the planet. However, while wandering on their search, they meet only an old man who is then killed by the wild girls. He is shot after he refuses to give away a gramophone, the only object which connects him with the old civilization. The women, however, continue their wandering in the wild. In the case of this film, it is worth mentioning its formal aspect. Jiří Macák observes the actions of the characters through the eye of the camera from the distance, which intensifies the catastrophic vision of the film (the director engaged only non-professional actors to play the roles of the women; as a result, in a way, they discover what they are able to portray in front of the camera on their own).

Then, after 1968, when a two-decade-long period of normalization began - that is the consolidation of a system connected with the fact that censorship was once again tightened - the previously mentioned crazy comedies dominated the science fiction cinema. They are all based on a similar plot development - the Czechs surprisingly became responsible for the lot of the whole world. The following work with its narrative structure is an example of such a film. A film directed by Jindřich Polák in 1977, Tomorrow I'll Wake Up and Scald Myself with Tea (Zitra vstanu a opařim se čajem) also focuses on the problem of a possible nuclear attack; in this case, time travel to the past might help Hitler win the Second World War. The plot is ambiguous: the main villain, Klaus Abard, is the leader of a Nazi group which wants to deliver a nuclear weapon to Hitler using a method invented in the Czech Republic. ${ }^{10}$ A travel agency called Universum, which organizes holidays into the past, is located in Prague. The dialogue in the film emphasizes that it is the Czechs, not the Americans, who are the pioneers of this kind of travelling. What is more, the American couple who appear in a supporting role, are portrayed as silly, naive people who treat the hijacking of the spaceship as just another adventure.

${ }_{10}$ Paulina Haratyk gave a lecture entitled An Atomic Bomb - "One of the Most Beautiful Views in the World", at a conference during the Political Cinema Week (Tydzień Kina Politycznego) on 16th May, 2014, in Cracow. She presented interesting ways to diminish the effects of using nuclear weapons. A picture presenting a test explosion on Bikini Atoll became an inspiration for, e.g.: the organization of the Miss Atomic Bomb contest with hairstyles in the form of a mushroom cloud resulting from an explosion, cakes in the same shape and propaganda films of different kinds. 
Prague in the future looks pretty much the same as the contemporary capital of the Czech Republic - the future makes it possible to travel in time and brings a few other inventions, but it is not a vision of radical changes (as it was in The Man in Outer Space). It is a classic comedy of misunderstanding - the main characters arrive at Hitler's bunker three years earlier than they expected so it is hard to convince the Führer that he will shortly be defeated. As the German army after another victory is already near Moscow, the travellers from the future are treated as liars and sentenced to death. The only thing that might help them survive is a movie released in the future presenting the forthcoming events. In a very unusual sequence for a comedy genre, one might see Hitler watching a film presenting his own collapse: the Nuremberg trials, the capture of the Reichstag, etc. In addition, it reflects a hybridization of the Czech cinema, as more important than the form of the films is the fact that behind the facade of an entertaining cinema they tried to convey a certain ideological meaning and furthermore, the films were unappreciated by the critics but highly popular with audiences. Although one might have doubts about their artistic value, they are an important phenomenon in the Czechoslovakian cinema, which should not be forgotten when discussing the elements of the science fiction genre.

\section{On the Margin of History - The Polish Science Fiction Cinema}

The tradition of the Polish science fiction cinema is not as rich as that of the Czechoslovakian film industry. In the Sci-fEAST database there are only about fifty Polish films of this genre and over twice as many Czech films. It is worth remembering, though, that Polish filmmakers touched upon similar subjects - in their productions one might see a reflection on that time; however, their perspective on the issue is totally different from Czech directors. It is worth mentioning $A$ Spy in a Mask (Szpieg $w$ masce, 1933) by Mieczysław Krawicz rather more as an item of curiosity than a film meeting the requirements of the genre. However, when The White Disease was produced at the River Vltava, Krawicz made a film in which a similar question is discussed: "The forthcoming war is going to be the collapse of humanity", and one of the scientists works on a device which will make it possible to stop enemy tanks and planes. The scenes set in a laboratory are only a background for spy intrigue in which foreign agent, Rita Holm, played by the Polish singer and actress, Hanka Ordonówna is engaged. The woman tries to seduce the scientist's son in order to come into possession of the plans for an invention. The intrigue is a pretext for a melodramatic thread during which Ordonówna shows off her acting and singing skills by performing her biggest hits. Unfortunately, an interesting science fiction concept does not end with a moral. In the last scene, Rita Holm dies in the arms of her beloved, but the audience do not learn 
anything about the future of the invention nor if it would have changed the course of history.

It was not until the 1960s that production of post-war science fiction films began. In 1959, The Silent Star (Milczaca gwiazda), a coproduction of the Polish and the German Democratic Republic producers directed by Kurt Maetzig, was released. However, the Polish producers did not play an important role in the project and the coproduction of the film was a 'propaganda exercise', this is why I will not focus on this work. One of the first attempts of this type was made exclusively by Polish producers - a science fiction series produced in the Studio of Small Film Forms SE-MA-FOR. Short films such as Associate Professor H. (Docent H., 1964) and The First Pavilion (Pierwszy pawilon, 1965) were produced in the days when, as director Janusz Majewski says, the Polish science fiction cinema was developing and "special effects" were created in the completely amateur conditions of SE-MA-FOR's trick workshop. ${ }^{11}$ The two films conveyed a hidden message against totalitarianism and the incredible story in the end turned out to be yet another dream of Professor Fos. The more interesting The First Pavilion concerns experimentation with the miniaturization of people; the idea being that when natural sources are shrinking, breeding a new dwarf race will make it possible for people to survive. Those selected to participate in the experiment are not aware of the situation and are kept in the first pavilion by a crazy scientist. The effect of miniaturization of the characters was produced solely with the use of perspective and special lenses. After some years, Majewski returned to the science fiction genre subsequently producing a series of films entitled "The Incredible Stories".

While the Czech cinema is famous for its adaptations of Čapek's prose, Polish filmmakers usually allude to Stanisław Lem's stories, even though the writer was very critical of attempts at film adaptations of his works. The only film accepted by Lem was Roly-Poly (Przekładaniec, 1968) by Andrzej Wajda, a little more than twenty-minute film, based on a short-story "Do you exist, Mr. Jones?". ${ }^{12}$ This grotesque comedy tells the story of a racing driver, Richard Fox (excellently played by Bogusław Kobiela) who because of road accidents has a series of transplantations. As a result, his body is built of many parts and a growing number of donors. Consequently, many legal problems develop - on one hand he cannot get insurance after his brother dies as his organs have also been transplanted to his body and from a legal point of view, the person whose organs are alive is treated as the one who lives, no matter in

11 J. Majewski, Retrospektywka, Wydawnictwo Literackie Muza S.A., Warszawa 2006, p. 207-208.

12 Then, Wajda planned to film The Futurological Congress by Lem but the writer did not approve of the idea, as he thought that in those times animation techniques were not developed enough to produce good effects. cf. A. Wajda, Kino i reszta świata. Autobiografia, Wydawnictwo Znak, Kraków 2000, p. 252. What is interesting, in 2013 Lem's story was presented in The Congress by Ari Folman in which he uses an advanced technique of linking together digital pictures with classic animation. Polish filmmakers also took part in this multinational production. 
whose body they are placed. Furthermore, it complicates Fox's personal life as well, as for his late brother's wife he is simultaneously a brother-in-law and partly a husband. Crowds of people gather outside the front of the institute's building where these incredible transplants are being carried out, ready to sell or trade any of their own organs. Wajda's film touches upon the issue of interference with human nature often discussed in science fiction films. The reason why Lem approved of the film was the fact that it was a comedy which enabled the viewers to take a futuristic stage design with a pinch of salt. The writer believed that the economic restrictions imposed on the Polish cinema would make it impossible to produce real and ambitious science fiction films. It is difficult not to agree with the author of Solaris, as to a great extent, national science fiction productions from this time were usually black and white, simple and used only a few actors, or television productions usually with no special effects, not to be compared with high-budget projects. The exception are those films whose goal was to compete with Hollywood such as another coproduction of Polish and East German Republic producers, MMXX Signals (Sygnaty MMXX, 1970), treated as a response to Stanley Kubrick's 2001: A Space Odyssey released two years earlier.

The last short-length film which is worth mentioning is Through the Fifth Dimension (Poprzez piaty wymiar, 1973) by Marek Nowakowski as it deals with a rare subject in the Polish science fiction cinema - time travel. In comparison with the Czech cinema, however, where the characters travel to the past in order to e.g. kill Einstein to stop the development of nuclear physics so that scientists would not be able to make an atomic bomb, ${ }^{13}$ in Nowak's film, based on a literary short story by Konrad Fijałkowski, the concept of changing the course of history was not taken into account. As a result of an experiment, the main character time travels only a few days into the past and does not interfere with an alternative reality but merely writes down his experiences while the existence of a fifth dimension is explained to the audience in a really simple and straightforward way.

When it comes to full-length films, On the Silver Globe (Na srebrnym globie) by Andrzej Żuławski is an exceptional project both from the point of view of the author's vision and of the scale of the production. The production was stopped in 1976 when the most of the film had already been shot. As a result, when production resumed over a decade later (it was completed in 1987), it turned out to be impossible to continue the project in the same form. Some of the props and sets had been damaged; what is more, it proved to be impossible to shoot additional scenes of a multi-threaded plot. It was an open secret that Żuławski was withdrawn from the film production because he significantly exceeded the budget (a completely unprecedented situation in socialist cinema) as his epic was filmed in several different places - Poland, Mongolia

${ }^{13}$ I.e. a comedy I Killed Einstein, Gentlemen! (Zabil jsem Einsteina pánové, 1969, directed by Oldřich Lipský). 
and Caucasus. It is an exceptional example of a film whose formal side is not integral as the fragments added in 1987 present Warsaw of that time. For instance, the scene going down to a laboratory was filmed in a long hall of an underground passage, and an over-diegetic commentary adds the information which originally was to be filmed. With regard to the plot, the narration takes the form of the vision of the director from 1976, i.e. a complex philosophical story about a few generations of space castaways on a planet populated by savages, this is why I put it in chronological order before the films of the 1980s.

Piotr Szulkin in War of the Worlds - Next Century (Wojna światów-nastep ne stulecie) who set the story in the year 2000, saw for himself how dangerous the creation of a future reality was. The director described a world ruled in a totalitarian way and made television the main medium of propaganda. The film was completed in 1981 but its premiere was postponed for two years so that the film would not allude to the martial law which had been introduced in those times in Poland (December 13, 1981, lifted on July 22, 1983.) Szulkin dedicated his film to George Orwell and the film alludes to his novel Nineteen Eighty-Four. Human beings are categorized by identifiers implanted in an ear; the iconography of science fiction intermingles with socialist realities, as the population records are evidence of friendship with mysterious Martians, and the committee before which the protagonist, Iron Idem, stands alludes to a socialist system. An allegorical vision of a society manipulated by the government also comes back in other Szulkin science fiction-stylized films.

In the same year as the premiere of War of the Worlds, cinema audiences were able to see one more metaphorical science fiction film, this time in the convention of a comedy and probably the most popular film of the genre Sexmission (Seksmisja, 1983) by Juliusz Machulski. The director used the science fiction/fantasy comedy genre many times. The most interesting example of this is present in two of his works from the 1980s (in 1987 he also produced Kingsajz) as there is a hidden meaning in them. In Sexmission, two volunteers, Max and Albert, decide to take part in a ground-breaking experiment during which they are put into hibernation. While they are asleep, a nuclear war breaks out which is why they are woken up half a century later when, as becomes apparent, only women have survived on the Earth and Her Excellency rules them in an absolute way. The men cannot adapt to a feminine futuristic world, which is a source of many humorous situations, however, the finale provokes deeper thought. The heroes manage to make their way to the surface where normal life is still going on and everything that they treated as a new apocalyptical reality turns out to be an enormous illusion made up by Her Excellency who in fact is an impotent man. When taking into account the hidden message of this production, and bearing in mind which former political system it alludes to, one might observe that of all Polish science fiction films, this vision, even though presented in a serio-comic manner, might be treated as the most daring. 


\section{An Attempt at Comparison}

The previously mentioned titles were selected from a few dozen science fiction films which I watched as a part of the work on the Sci-fEAST project. In my opinion, they present the most interesting, from the point of view of plot, as well as the most representative examples of the issues dealt with by filmmakers of these two Middle-European cinemas. They are an example of the science fiction genre - a 'genre facade' behind which filmmakers worked in order to allude to the socio-political situation with which they were familiar, often trying to diagnose it, even though they did not regard their films as purely science fiction. On this basis, a distinction between Czech and Polish films is clear to see. In the Czech films, the main narration is based on the assumption that the Czechs might actually change the course of history as e.g. all the ground-breaking inventions are made in Prague. The Czechs with the use of the science fiction genre try to heal the complex of a minor and insignificant nation, which does not often play an important role in world history. This is why I believe that in science fiction films the filmmakers were trying to change this image. Even though the characters are still awkward and helpless, reflecting the typical attitude of "a small Czech man" (Čecháček), the most typical example of which is the soldier Josef Švejk, at the same time, they are no longer consigned to the margins of history. In each film, the story points to a moment when the Czechs have a real influence on the future of the world. Especially when they are able to save the planet from destruction. An important trend of the science fiction genre was also the comedy convention which empowered authors to dream about the Czech contribution to the future history of mankind. However, taking into account the past regime, daydreaming about the future seemed to be risky - one should travel in time to the past only. Stories of this type were not a point of interest for Polish science fiction authors - it is hard to find any films in which the Polish people could influence the future on a global scale. ${ }^{14}$ They rather tend to convey universal meanings and create allegorical plots, developed in television and later presented in full-length feature films. While the Czechs tend to put themselves in the centre of history, Polish filmmakers rather stay on its margins, usually making films concerning a reflection on a development of technology, not related to the Polish nation only. The second important trend concerns those films which are an allegory of a political situation. Nonetheless, these allegories either glorified the communist ideology (mainly the co-productions which

14 E.g. a contemporary comedy Ambassada (2013, directed by Juliusz Machulski), in which the inhabitants of one of the tenement houses unwillingly travel in time to the year 1939 when the German Embassy was located in their house. In contrast to the films concerning the dictatorship of an entity, made before the war and which attempted to diagnose the current situation, and not only to describe it, Machulski's film is only an example of a repetitive usage of a popular alternative history theme. 
I did not take into account) or conveyed an opposite but thoroughly hidden message, which in order not to bring to mind direct associations with a political system were transferred to the area of a completely different time-spatial reality. If the critique of the political system was too obvious, as in Szulkin's work, the films, due to censorship, were prevented from being released. Polish science fiction filmmakers did not make science fiction comedies as often as the Czechs did. Till 1989, simple individual films were far more popular than productions made for a wide audience. It is of course only a general and demonstrative representation of the genre to which there are many exceptions. I believe, though, that they do not change the perception of the history of Czech and Polish science fiction presented in this article but even make it more interesting. 